\title{
Inhaler Dosing Unit
}

National Cancer Institute

\section{Source}

National Cancer Institute. Inhaler Dosing Unit. NCI Thesaurus. Code C62275.

A dosing unit equal to the amount of active ing redient(s) contained in an inhaler. 